\title{
A HATÉKONYSÁG NÖVELÉSÉNEK LEHETŐSÉGEI AZ ÖNKORMÁNYZATOKNÁL
}

A tanulmány röviden bemutatja a magyar önkormányzati szektor feladatrendszerét és a finanszírozás jelenlegi helyzetét, valamint az Új Közmenedzsment módszer hazai alkalmazása nyújtotta lehetôségeket. A tanulmány ambíciója az önkormányzati szektor szorult gazdasági helyzetének vizsgálata kapcsán a gazdaságfejlesztés és a hatékonyságnövelés lehetôségeinek vizsgálata. A szerzố menedzsmentmódszereket ajánl a hivatali vezetés hatékonyságának növeléséhez, kiemelve a különbözó módszerek alkalmazásának problémái mellett azok hosszú távú elốnyeit, hasznait.

Kulcsfogalmak: önkormányzati szektor, gazdaságfejlesztés, Új Közmenedzsment, a közigazgatás területi integrációja, a hivatali múködés hatékonysága, az irányítási folyamatok korszerúsítése, teljesítményorientált menedzsmenttechnikák

A közigazgatás tradicionális modelljét hazánkban az 1980-as évektól kezdődően egy új vezetési megközelítés váltotta fel, melynek elemei a piac vezérelte közigazgatás, a közszolgálati menedzsment reformja, a saját bevételek növelését célul kitưző vállalkozó önkormányzat. Az új modellben kihívások érik a klasszikus weberi bürokráciát, a közvetlen kormányzati szolgáltatásszervezést és -nyújtást, a politikai és közigazgatási ügyek olyan elválasztását, amelyben a feladatok végrehajtása az elsődleges szempont. Az állami beavatkozás és támogatás - melyek tökéletesen hatékony piac esetében szükségtelenek lennének - a hiányzó hatékonyság növelésére irányulnak. A fejlett országokban a teljesítményorientált önkormányzati reformok jelentôsen modernizálták a költségvetési gyakorlatot és növelték a gazdálkodás hatékonyságát.

A magyar önkormányzati szektor költségvetési gyakorlatát és a helyi gazdaságfejlesztésben betöltött szerepét nagy kihívások érik, az önkormányzatok többsége egyre nehezedố gazdasági feltételekkel szembesül, miközben feladatai és az ,ügyfelek” (állampolgárok, vállalkozók, állami intézmények, civil szervezetek) önkormányzattal szembeni elvárásai fokozódnak. Az államháztartás ezen alrendszerének pénzügyi helyzete, az önkormányzati szektor külsố forrásbevonó képességének, a közpénzekkel történő gazdálkodás átláthatóságának és hatékonyságának növelése, valamint a hivatali múködés korszerúvé és ügyfélbaráttá tétele lényeges területe az államháztartási reformnak. Az önkormányzati múködés átalakításának és sikeres reformjának két kulcseleme nézópontom szerint: a gazdaság fenntartható és versenyképes fejlesztése mellett a gazdálkodás, a hivatali múködés hatékonyságának növelése. A hatékonyabb múködés a jelenlegi feladatvégzés racionalizálását, a nyújtott közszolgáltatások minőségének javítását, alacsonyabb költségét jelenti. Az önkormányzatok éles versenyhelyzetben vannak a forrásokért, a támogatókért. Az önkormányzati fejlesztések külső forrását az egyre csökkenő állami finanszírozás mellett a pályázati források és a hitelek jelentik. A fejlesztésre fordítható források másik csoportja a saját bevételek növelésén túl a területi közigazgatás térbeli integrációjával, a feladatellátás racionalizálásával és az önkormányzati múködés hatékonyságának javításával teremthetố elô. Határozott stratégiai célok mentén dolgozó, hatékonyan és áttekinthetôen gazdálkodó önkormányzat nagyobb eséllyel indul a külsố forrásokért folytatott versenyben is.

A publikáció elsố részében a helyi önkormányzatok feladatrendszerének egyik kulcsfontosságú elemével, a gazdaságfejlesztés lehetőségeinek vizsgálatával foglalkozik, majd az önkormányzati finanszírozás helyzeté- 
nek áttekintő értékelése után az Új Közmenedzsmen vezetési paradigma által javasolt pótlólagos forrásbevonás lehetőségei kerülnek a középpontba. Az új közigazgatási modell által már a fejlett országok üzle és állami szektorában egyaránt sikeresen alkalmazot gazdaságfejlesztési eszközök hazai alkalmazásának problémái mellett a hatékony hivatali múködést nagyban elősegító menedzsmentmódszerekkel foglalkozik a tanulmány, részletesen tárgyalva az egyes módszerek alkalmazásának problémái mellett a hosszú távú elónyöket és hasznokat.

A tanulmány elkészítésének módszere a vonatkozó szakirodalom kutatási eredményeinek összefoglalásán tú a szerző saját kutatására, az önkormányzati vezetókkel és munkatársakkal folytatott személyes mélyinterjúin túl a tényeken alapuló meggyőződésére alapozott munka.

\section{Az önkormányzatok feladatrendszere}

Az önkormányzatok feladatkörét részletesen a helyi önkormányzatokról szóló 1990. évi LXV. törvény (Otv.) 1. és 8. §-ai szabályozzák. Az egyes feladatcsoportok végrehajtásának eszközrendszere rendkívül differenciált, magába foglal közhatalmi, finanszírozási, tulajdonosi és vállalkozói elemeket egyaránt. Az önkormányza törvény alapján az önkormányzati szerepkör lényegében három nagy terïletet fog át Az önkor három nagy teruletet fog á. Az ônkormányzatok mi az állami struktura ieszei kötelesek a helyi közszolgal tatasokar szevezi abban a korben, amelyekre az állam a polgáraival szemben jogszabályokban kötelezettség vallalt, például oktatás, egészségügyi, szociális ellátás, közmúvelódés, gyermek- és ifjúságvédelem, tömegközlekedés, közvilágítás, köztisztaság, vízellátás, kommunális szolgáltatások nyújtása.

A kötelezö önkormányzati feladatok második csoportja a hatósági-igazgatási feladatok köre, melyek végrehajtási felelőssége megoszlik a képviselő-testület, a polgármester és a jegyzó között.

A harmadik feladatcsoport a helyi gazdaságfejlesztés, ami átfogja a stratégiai tervezést, területrendezést, gazdasági támogatást, infrastruktúra-fejlesztést, telepilésmarketinget, az idegenforgalom szervezését, foglalkoztatáspolitikai feladatokat stb.

Szigorúan véve csak az elsó és a harmadik feladatcsoport tartalmaz konkrét fejlesztési feladatokat, tágab értelemben azonban a közszolgáltatások, közjavak m nőségével szemben támasztott elvárások és a közpénzekkel való gazdálkodás hatékonyságának szakmai követelménye miatt szinte minden önkormányzati felada igényel fejlesztést, korszerúsítést. Az önkormányzato fố célja a területükön éloó lakosok életminôségének javítása, amely a közszolgáltatások fogyasztói elvárás- nak megfelelő színvonalának javításán túl a gazdaság fejlesztését is magában foglalja, hiszen a sikeres gazdasaggfejlesztés biztosítja hosszú távon a stabil és adekvát mértékú bevételeket az önkormányzat számára. A településfejlesztés saját olvasatomban a település társadalmi, kulturális és gazdasági erôforrásainak, környezeti minőségének, infrastruktúrájának olyan stratégia alapján történő módszeres fejlesztése, amely a fenntartható fejlódés érdekében megteremti a település lakossága számára az életszínvonal növekedésének, az életminő́ség javulásának egyensúlyi feltételeit, elkerïlve a jövó ség javulásának egyensilyi felételit, elkerülve a jovố A fejlesztéseknek mindenekelőtt versenyképesnek és fenntarthatónak kell lenniük. A gazdaságfejlesztést a helyi társadalom számára azok a belső strukturális változások jelentik, amelyek megjelenhetnek a termelési tényezókkel történő hatékony gazdálkodásban, az eróforrások jobb hasznosításában, új munkahelyek létrehozásában, a közösség kulturális fejlődésében. A fejlesztési programok akkor érik el céljukat, ha a fejlesztések hatása tovagyúrúzik, ami hosszú távon tartós versenyelónyt jelent. Az önkormányzatok vezetésének, képviselö-testületének a gazdaság fejlesztésében kialakuló motiváltságát nagyban befolyásolja a helyi gazdasági-társadalmi légkör, a lakosság igényei, a település gazdaságföldrajzi adottságai. Az innovatív szemléletmód hiánya a korrupció és ív szemelmód hianya, a korrupció és lrácia a gazdaság fejlódését és versenykésségét jelentősen ronthatja.

Stratégiai tervezéssel az önkormányzatok koncepciózus keretekbe rendezhetik gazdaságfejlesztési aktivitásukat. A helyi gazdaságfejlesztési potenciálok, melyek elsősorban a gazdasági-társadalmi környezet erôsségében, új munkahelyek teremtésében, megfelelố infrastruktúra kialakításának és fenntartásának képességében fejezhetók ki, olyan fenntartható gazdasági növekedést jelentenek, amely a magas foglalkoztatottsági ráta melletti magas termelékenységból és a térség gazdaságának nyitottságából származik (Lengyel, 2003). A gazdaságfejlesztés lehetôségeinek feltárásához és a feladatok kijelöléséhez településszociológiai tényezóket is figyele bell venni, hiszen az egyes telepilések a hely

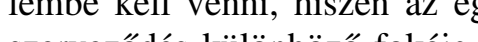

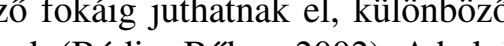
igényekkel rendelkeznek (Bodi - Bôhm, 2002). A helyi gazdaságfejlesztés alapja a helyi fejlesztési terv, illetve településfejlesztési koncepció. Az Európai Unió regionális poitikajában való részvételhez szükséges az állam szféra minden szintjén történő programozás. Valamennyi településnek kiforrott tervvel, jövóképpel kell rendelkeznie az igényelt támogatás eléréséhez. Az a település, amely nem fogalmazza meg és fogadja el körültekintố tervezés és egyeztetés nyomán a célkitűzéseit, nem számíthat a fejlesztési programokban való érintettségre.

\section{A magyar önkormányzati szektor finanszírozási rendszerének sajátosságai}

Magyarországon az önkormányzatok finanszírozása szempontjából a településhálózat és a helyi önkormányzati rendszer elaprózottsága komoly méretgazdaságossági problémákat jelent az önkormányzato gazdálkodása és a közszolgáltatások biztosítása szempontjából. Hazánkban az urbanizációs fejlődési utak jelentősen eltérnek, összességében a települések kb. 54\%-a ezer főnél kisebb népességszámú. (A tek kb 5́ç lésszociológiai tényezôkrô lâsd bơvebben Beluszky, 1999.) A helyi fejlesztéseknél rendkívül eltérő az egyes
önkormányzatok mozgástere. A kisebb települések önkormányzatok mozgástere. A kisebb települések
többnyire financiális okok miatt alig képesek puszta többnyire financiális okok miatt alig képesek puszta
múködésüket fenntartani és hatást gyakorolni a helyi

múködésüket fenntartani

A rendszerváltozás óta jelentősen csökkent az önkormányzatok autonómiája, amit legjobban a személ jövedelemadó önkormányzatoknak történő csökken mértékú visszautalásával szemléltethetek: amíg a rendszerváltozás után a személyi jövedelemadó ötven százaléka maradt a helyhatóságoknál, addig mostanra csupá nyolc százalék (Deli - Vigvári, 2006). A csökkenő adobevétel helyett normatív támogatást nyújt a kormány,

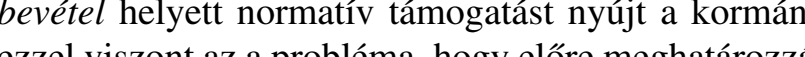
ezzel viszont az a reg a forrás felhasznáhatóságának körét, ami az önkormányzatok onálóságának csökkentése mellett a forrásokkal való szabad rendelkezés korlátozását jelent A normatív allami tamogatások gyakran nem elegendóek a múködési feladatok finanszirozására, ezért a helyhatóságoknak a saját bevételeik terhére kell kipótolniu azt. Az állami támogatások több mint négyötöde múkoodési célú juttatás, $\mathrm{s}$ alig egyötödös arányt képviselnek a fejlesztési célú támogatások. Az állami támogatáso belül figyelmeztetô az önhibájukon kívül múködésképtelen helyzetbe került (,„önhiki”) önkormányzatok részarányának és támogatásuknak az emelkedése, ami az önkormányzatok egyharmadát érinti. A finanszírozá rendszer kiegyensúlyozatlansáǵ́t mutatja az a tény is hogy ha ö hogy ha az onkornanyzatok har mada kerult onnhibáj kivil fizeteskepelen helyzebe, akkor az nem lehet csupán az egyes onkormányzatok felelóotlen gazdálkodásának az „eredménye”. Az onkormányzatok szoru gazdasági helyzete az állami céltámogatások, az Europai Unió nyújtotta támogatások felhasználhatóságát megkérdőjelezi, hiszen a pályázat elnyeréséhez szükséges onresz mértéke nem, vagy csak nehezen biztositható. A külső források közül a hitelek szerepe a finanszírozásban továbbra is elenyésző, elsősorban a sajầ erố hiánya, valamint a szigorú hitelbírálati szemponto miatt, mégis igény van ennek a bevételi forrásnak a no- velésére, a gazdaságfejlesztésbe történő beruházáson túl például az EU-támogatások által megkövetelt saját eró biztosításában (Vigvári, 2006)

Az önkormányzati finanszírozási rendszer továbbfejlesztése azt a célt szolgálja, hogy a területi önkormányzatok feladataik és a kívánatos fejlesztések ellátásához stabil bevételi bázissal rendelkezzenek, finanszírozásuk hatékony rendszerré váljon (Vigvári, 2006). Hazánkban a decentralizáció során elsősorban az adóztatási rendszerek megváltoztatása, a központi és elyi szint közötti kiadások meoszása és a kapcsolóó pénzïgyi ösztönzók múködési mechanizusa biz作

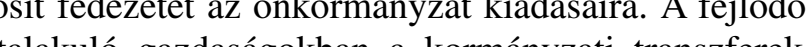
atro nek, mint finanszirozási konstrukciơknak, lényegesen nagyobb a jelentősége és módszertani támogatottsága, mint a vállalkozó ơnkormanyzat példajakent szolgálô fejlett államokban. A jelentốs eltéréseket mutató jövedelmi viszonyok, a bizonytalan gazdasági környeze miatt szinte lehetetlen kizárólag racionálisan decentralizálható adókból fedezni az önkormányzatok kiadásait, azt is figyelembe véve, hogy a lakosság nem terhelhetố túl. Az Európai Unió támogatásainak felhasználhatóságát nagyban érinti a pályázáshoz szükséges önerő mértéke, ugyanis az önkormányzatok már az allami központi címzett- és célt́́m oúnások már es cem arra több

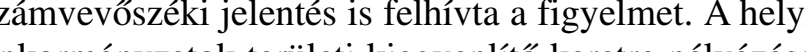
onkormannyzatok területi kiegyenlító keretre pályázása során számos esetben hátrányt jelent a GDP alapján számított, megyei szinten megállapított onresz aránya, mivel a megyei szinten értelmezett GDP elfed olyan nagy differenciákat, amelyek minden polarizált településstruktúrájú megyében felmerülnek. A megyei szint túl nagy aggregáció ahhoz, hogy a vállalható önrész mértéke egységesen megítélhetố legyen, ami korlátozza a támogatási forma elnyerésének eredeti célját, a területi különbségek kiegyenlítését.

Javaslataim összefoglalása: Központi szinten célszerú meghározni egy önkormányzati közszolgáltási minimumot, azaz az alapvetô szolóltáśa

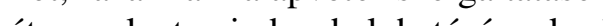

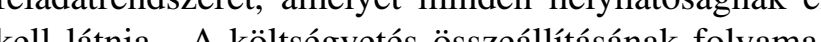
tón olyan törvényi szabályozókat kellene bépíteni, amelyek biztosítják a múködési költsé

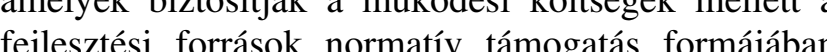
fejlesztési források normatív támogatás formájában torténó fedezettségét. Szükségesnek tartom az önkormányzati szektor külső forrásbevonó képességének növelese mellett a források felhasználásának ellenőrzését. A területi kiegyenlító keret hatékonyabban tudná ellátni kiegyenlító szerepét, ha a helyi önkormányzatok pénzügyi-gazdasági helyzetének figyelembevételével 
differenciálható lenne az egyes pályázók részére előírt kötelező önrész mértéke. A sajátos helyi viszonyoknak és adottságoknak köszönhetően az önkormányzatok gazdaságfejlesztésének sikerében jelentốs különbségek tapasztalhatók, melyek kezelésében meghatározó az önkormányzat vezetése, menedzsmentje.

Az Új Közmenedzsment vezetési paradigma és a hatékonyság növelésének lehetốségei

A fejlett államokban alapvető változások mentek végbe az önkormányzati intézményrendszerben: a közszo gáltatások biztosit́́n új, a patennasta modiben idegáltatások bizto tína ú, a patenalista modellben idegen, vállalkozó típusú és fogyasztooorientált megközeaz önigazgatás és a hatékonyság kapcsán. A közszfér reformlépései már a vállalatoknál jól bevált menedzsmentmódszerek adaptálásán alapulnak.

Az Új Közmenedzsment célja a gazdálkodás hatékonyságának növelése mellett a közszolgáltatások minőségének javítása. A vezetési paradigma módszerei elsősorban az állam szerepének visszaszorítása, az irányítási folyamatok korszerúvé tétele, racionális tervezés, szervezés, irányítás és ellenôrzés megvalósitása, információs rendszerek támogatásával (Hajnal - Gajdusek 2002). Az új vezetési paradigma modelljében az ö mányzati hivatal iŕ́ńt́́́j a polǵ́ mányza hiva ú szakmai szenos is. Persze, ahol van rá anyagi for ás, ott kulön városmenedzsert is lect alkalmazn. Hazánkban a jegyzôi feadatkör tồ ényben tôrténó rogzzitése azt a célt szolgálja, hogy a polgármesteri hivatalt politikai befolyásoktó mentes közigazgatási szakember irányítsa. Világszert egyre nagyobb hangsúlyt kap a közszolgáltatások piaci alapú ellátása. Költségmegtakarítást és hatékonyságjavulást eredményezhetnek az önkormányzati társuláso âltal közösen nyujjtott szolgáltatások. Az önkormány-

ialakításával kell számolni, amelyek magukba foglala hazai társfinanszírozíst, a hitelhez és a pályázaoürkséges önrész biztosítását, valamint valószíuúsíthetố a PPP (Private Partnership Project) struktúra további terjedése és erôsödése.

Az önkormányzatok új vezetési paradigma alapján történó múködésével szemben két alapvetơ kritériumnak kell teljesülnie: segítse eló, hogy a települések aktív gazdaságfejlesztést folytathassanak, valamint a hatékony gazdálkodás keretein belül jó minőségú és ügyfélbarát közszolgáltatást biztosítsanak. Hazánkban a gyenge fejlesztési politika többnyire elégtelen minő́cégú közszlgáltatásokkal párosul. Az önkománzatok forráshelyzetének javulása al. Az ótele ma hogy a hazai települósek megerósítsék gazdúng versenyképességüket és kiépítsék sikes senyképességüket és kiépítsék sikeres telephelyi politikajukat. Az onkormányzatok tobbnyire sajă vagyonuk felélésével, az önkormányzati vállalatok privatizálásával tudják csak finanszírozni a közszolgáltatásokra vonatkozó növekvô elvárásokat, a gazdaság fejlesztésére gyakran nem jut már kapacitás.

A helyi közösségek életminőségének javítása és a fejlesztési mozgástér bővítése jelentős tôkeerőt követel, ezért a központi kormányzati és pályázati források, támogatások mellett kulcsfontosságú tényezô az önkormányzat saját forrásainak növelése, az önkormányzatok forrásbevonási képesśǵ Unió taǵl Unjo taja alápjan iranyelv a helyi kozszolgaltatasok finanszírozásat az egyéb források mellett elsôsorban sajá bevételekbón és a helyi közósségtôl beszedett adókból fedezni (Vigvári, 2006). Az önkormányzati adózás rendszernek azonban figyelembe kell vennie a helyi társadalom és gazdaság teherbíró képességét.

Az 1. táblázat a közszolgáltatások fejlesztésének régi és új típusú vezetési paradigma által alkalmazott finanszírozási forrásait foglalja össze.

A közszolgáltatások fejlesztésének finanszírozási forrása

(Forrás: saját)

\begin{tabular}{|l|l|}
\hline \multicolumn{1}{|c|}{ Régi paradigma alapján } & \multicolumn{1}{c|}{ Új paradigma alapján } \\
\hline - A központi szint által a helyi szint számára biztosított állami & - Saját bevételekek növekvó bázisa \\
támogatások & - Piaci alapú vállalkozásmenedzsment \\
- Kedvezményes kormányzati hitelkonstrukciók & - Kormányzatat támogatások és a koncessziós hitelek \\
- Nemzetközi szervezetektóll, Európai Uniótól származó & egymásra épitett rendszere mellett \\
támogatások, hitelek & szofisztikált adósságszolgálati megoldások \\
\hline
\end{tabular}

zati fejlesztố beruházások feltételezik az addicionalitás és a kofinanszírozás elvének gyakorlati megteremtését, ami megköveteli az önkormányzati szektor saját bevételi bázisának és kölcsön-, illetve magántóke-bevonó képességének növelését. A jövő́ben olyan konstrukciók

$\mathrm{Az}$ új közszolgálati menedzsment szerint a fejlesztési források alapja az önállóság fokozása. Az új közszolgálati menedzsment modellje is számít a kormányzati transzferekre, melyek célja nem elsősorban az önkormányzati intézmények finanszírozása, hanem az államilag támogatott közszolgáltatások megfeleló minőségú biztosítása a társadalom számára.

Az új vezetési paradigma a következő finanszírozási forrásokat javasolja az önkormányzati szinten gyakran előforduló fejlesztési finanszírozási stratégia megalkotására és fenntartására:

• kis- és közepes méretú vállalkozások kedvezményes hitelprogramja

• egy vagy több önkormányzat együttes kötvénykibocsátása,

- speciális forgóalap kezelése (kormányzati és más donorok támogatásait, kötvénykibocsátását alapszerúen, kockázati közösség által kezelt megoldás).

A hitelfinanszírozás egy speciális módja, az önkormányzati kötvények nyilvános kibocsátása révén lehetőség nyílik számos tốkepiaci szereplő megtakaritásának elérésére, összegyújitésére. A kötvénykibocsátás során a finanszíroź́sban való közvetlen lakobsá

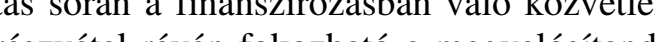
részvétel révén fokozhato a megvalosi

A kötvénykibocsátás hazai alkalmazását nehezíti a másodlagos piac hiánya, a méretgazdaságossági problémák mellett a kibocsátás magas költsége.

A fejlett államok: pl. Amerikai Egyesült Államok Kanada, Japán helyi gazdaságfejlesztési gyakorlatáb leggyakrabban használt Új Közmenedzsment vezetés paradigma által sikeresen használt gazdaságfejlesztési eszközök (Norton, 1994; Péteri, 1994):

Az önkormányzatok feladatellátásának optimalizálási lehetőségei (Forrás: Tanács, 2007. p. 3.)

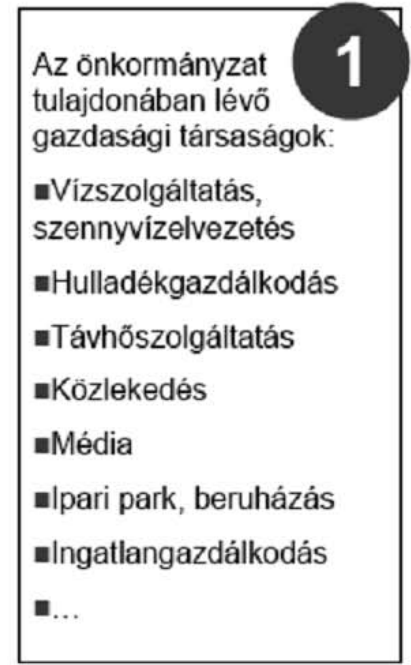

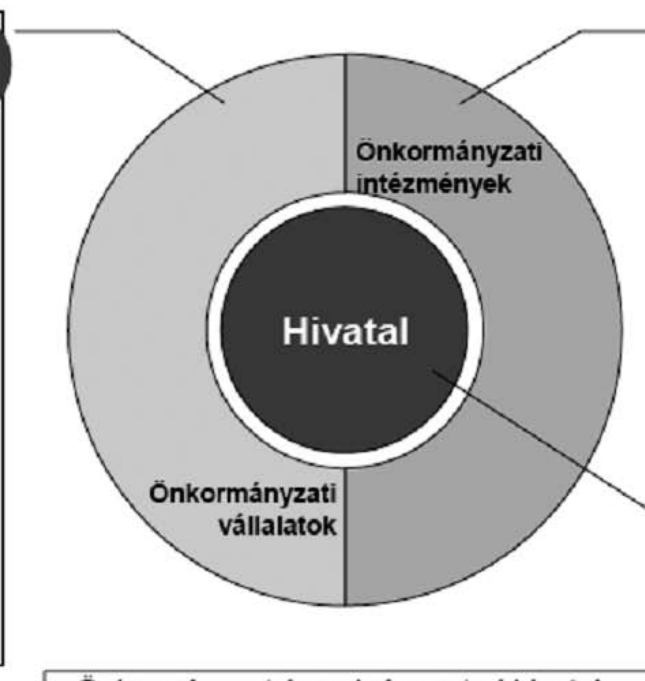

-Önkormányzat és polgármesteri hivata -Helyi közigazgatás

-Közfeladatok ellátása és az ellátás szervezése
- vállalkozóbarát adópolitika alkalmazása,

- telephely-biztosítás, kedvezményes hitelek nyúj, betidij-támogatási megállapodások,

szerinti alakítása,

- fejlesztési megállapodások,

az új technológiák letelepedésének ösztönzése, vállalkozói szaktanácsadás,

a helyi termékek támogatása, helyi munkahelybiztosítás, továbbképzés elősegítése,

a kutatás és innováció támogatása,

A fállalkozásaságfejlesztési eszközök többsége a hekaerôpiac szerkezetébe történő beavatkozást, a helyi önkormányzat foglalkoztatóként való megielenését segíti elő Számos nemzetközi fejlesztési lehetóség alkalmazását a hazai önkormányzatok anyagi helyzelényegében kizária például a garanciaváll h́́ vagy z önkormányzati hitelnyújtás intézményét, hiszen a legtöbb önkormányzatnak komoly terhet jelent már az öresz elóteremtése is. A gazdaságfejlesztéshez az oán

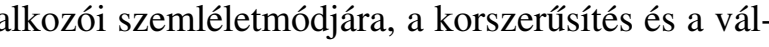
toztatás igényére van szükség, ezek hiánya jelentősen gijola a kezdeményezések megvalósítását.

VEZETÉSTUDOMÁNY 


\section{Az irányítási folyamatok korszerúsítése}

„A 'hatékony önkormányzati múködés' fogalmának tartalma a magyar polgármesterek gondolkodásába általában a 'korszerú, eredmény- és minőségorientát önkormányzati múködés' fogalmát jelenti” (Hajnal, 2007: p.11.). Az önkormányzati szektor reformja szakirodalom kutatásai (Hajnal, 2007) alapján elsődlegesen az irányítási folyamat korszerúvé és hatékonny tételéhez, valamint a közfeladatok ellátásának méretgazdaságossági okok miatt történő térbeli integrálás során önkormányzati társulások, konzorciumok alapításához kapcsolódik. Véleményem szerint prioritás kell élveznie a hatékonyság növelésének és az irányítási folyamatok korszerúsítését elősegító menedzsmentmódszerek alkalmazásának a közigazgatás tórségi integrációjíval szemben, mivel a feladatok végzésí inelécénének integrációja szükséges, de nem elégséges feltétele a szú távú hatékonyságnövekedésnek.

Az önkormányzati feladatellátás rendszerét három szinten érdemes vizsgálni (Tanács, 2007):

- önkormányzati gazdasági társaságok,

- önkormányzati intézmények

- önkormányzati polgármesteri hivatal szintjén.

A 1. ábrán látható feladatok összegyújtése után célszerú felmérni, hogy az egyes feladatok pontosan mennyibe kerülnek és milyen forrásból finanszírozhatók hatékonyabban.

A folyamatszervezési és szervezetkorszerúsítési munkák kiváltó okai között szerepel:

- az alapfeladatok hatékonyabbá tételének igénye

- az irányítási struktúrák korszerúsítésének igénye,

ideértve a döntéshozatal rugalmasabbá, gyorsab-

bá tételét is,

- a támogató - adminisztratív, belsố szakmai vagy múszaki szolgáltatói - tevékenységek költséghatékony elvégzésének igénye,

- megfelelố szolgáltatási színvonal biztosítása,

- a jogszabályi előírások, kötelezettségek, felelôssé-

gek miatt az ellenôrzési nyomvonal kialakítása

A közigazgatási rendszer korszerúsítésével kapcsolatos intézkedések keretében kiemelt hangsúlyt kap a kistérségek összehangolt fejlesztésének előmozdítása, az önkormányzati közszolgáltatások színvonalának emelése érdekében a többcélú kistérségi társulások alapítása.

\section{A területi közigazgatás térbeli integrációja - kisterrségi önkormányzati konzorciumok}

Az önkormányzati konzorciumok valós önkormányzati jogosultsággal nem rendelkezhetnek, csak intézményfenntartó-múködtető jellegú jogkörrel bírnak.
Az önkormányzati társulás racionális eszközökkel kistérségi kereteken belül oldja meg azokat a közfeladatokat, amelyekre megbízást kap az önkormányzatoktól.

A konzorcium jellegú múködésnek számos előnye van (Csizmadia, 2003):

- Az önkormányzatok és a társulás között egyenrangú szerzódéses kapcsolat jön létre, ahol a kötelezettségek, jogok, ár-érték arányok szabályozottak, mindkét fél a költségszemléletú gazdálkodásra ösztönzött.

- Az intézményirányítás, a szervezeti múködtetés szakmai és adminisztratív feladatait méretgazdaságos módon a társulás végzi el

- A társulás a közszolgáltatás ellátásának szervezőjeként valós szolgáltató pozícióba kerül, a lakossági igényekhez igazodva keresi a megfelelő ellátási formát, akár szerződéses kereteken belül. A szerződéses típusú kapcsolat lehetővé teszi, hogy a társaságok bővítsék a szolgáltatások körét például közbeszerzések lebonyolítása vagyongazdákodás, szakmai továbbé́pzása, vagyongazdalkodás, szakmai továbbképzések

- A finanszírozási döntések átkerülnének a helyi önkormányzatokhoz, az e célra felhasználandó támogatások beépülhetnének az önkormányzati normatívák közé. A többcélú társulásokban a feladatellátás szervezeti keretei átalakulnak, nő a munkaszervezetek által és a külső erőforrás bevonásával történő feladatellátás aránya.

Azállami ráfordítások felhasználásának hatékonysáa az önkormányzatok pénzügyi információs rendszerének hiányosságai miatt nehezen értékelhetố, azonban az Állami Számvevoószék jelentése (bővebben: www. vg.hu/index.php?apps $=$ cikk\&cikk $=233610 \& \mathrm{fr}=\mathrm{hs}$ - 83k) rávilágít arra, hogy a 2004-2008 közötti idôszakban a többcélú társulások megalakulása során az önkormányzatok társulási hajlandóságát a gazdasági kényszer mellett a többlettámogatások megszerzésének lehetősége fokozta. Az Állami Számvevőszék jelentése szerint kisebb javulás bekövetkezett ugyan a kapacitások kihasználásában, de a növekvő ráfordítások ellenére nem mutatható ki a közszolgáltatások szélesebb körében az ellátás színvonát hatékonyságát érintố lényeges az elláás szinvonáá, haténonyságát érintố lényeges elmozdús. Ezêt a jelentés hangsúlyozza a játosságait figyelembe vevó eljáŕsí tós és hấ ellátás sajatosságait figyelembe vevó eljárási és hatásköri rend szabályozásanak központi kidolgozása mellett az ösztönző támogatások igénylésének és elszámolásának emezhetővé és ellenőrizhetővé tételét.

Javaslataim alapján a hatékony közpénzfelhasználás érdekében szükség van az önkormányzati társulásoknak a közszolgáltatások struktúrájában betöltött szerepének pontos kijelölése mellett az önkormányzati finanszírozással való összehangolására, továbbá az ösztönző t mogatások feltételrendszerének felülvizsgálatára és értékelésére. A finanszírozó és a feladatellátást megvalósító szerep szétválása csökkentené a korrupció lehetőségét. A megyei önkormányzatok esetében az elórelépést az jelentené, ha belátnák, hogy a megyei szint az elosztó funkció elvesztésével intézményfenntartó-múködtetó szervezetté alakult, ahol az önkormányzati típusú testíleti döntéshozatali forma már nem múködóképes.

\section{Hatékonyságnöveló menedzsmentmódszere}

\section{alkalmazása}

Az önkormányzatok hatékonyságával kapcsolatos problémák már az alapvetó önkormányzati intézmények kialakulását követően megjelentek. A közszfér ból hiányzik az a hatékonyságot növelố motiváló erố, ami a vállalatoknál egyértelmúen a profit. Kutatásai alapján a közszolgáltatások ellátása tekintetében teljesen hiányzik a hatékonysági és a méretgazdaságossági kívánalmakat közvetíteni képes szakmai követelmények megfogalmazása, amelyeknek alapján a közszolgáltatások eredményei kimutathatóak lennének az önkormányzati szektorban. Az önkormányzat vezetőinek és munkatárainak passzív szemléletmódja részben és múr magyarázhá a polgám kapcsolatos ellenállásával, az innováció lehekapssolatos ellenálásával, az innováció lehe-
tőségének és képességének hiányával. Az öntőségének és képességének hiányával. Az önkormányzatnál elvégzett teljesítményértékelés gyakran a szükséges szakismeretek hiányára, a végzett munka lassúságára mutat rá, ezért a hivatali vezetésnek nem érdeke a változtatás, az alkalmazottaknak pedig a kezdeményezés. $\mathrm{Az}$ önkormányzatok vezetésének kevesebb mint a harmada alkalmaz hatékonyságnöveló eszközöket, és ahogy azt a 2. ábra szemlélteti, az egyes technikák elterjedtsége meglehetốsen alacsony, mindössze 8,8 és 29,4 százalék közé tehetố (Forrás: Hajnal, 2007).

A továbbiakban a tanulmány az egyes menedzsmenttechnikák alkalmazásának sajátosságait, problémáit, a sikeres alkalmazás hoszszú távú elốnyeit, hasznait vizsgálja, a szerző javaslatait, ajánlásait kiemelve.

A területi közigazgatás modernizációja területén mérvadó irány az e-kormányzás fejlesztése, ami a kormányzati funkciók gyakorlásához használt elektronikus/internetes eljárások összességét jelenti. A magyar e-kormányzat fejlesztésének fő stratégiai irányai a www.e- magyarorszag.hu-n közöltek alapján az ügyfelek igényeinek minél magasabb szinten történó kielégítése mellett a közigazgatás belső folyamatainak hatékonynyá tétele. Az önkormányzati szférát érintô racionalizálâsi intézkedések elsósorban az âllampolgári ügyintézés korszerúsítésével, elektronizálásával összefüggố (front-office) projektek, másodsorban a kormányzati intézmények munkafolyamatait támogató (back-office) rendszerek fejlesztései jelentik. Az ügymenet digitalizálása, beleértve az egységes közigazgatási adatmenedzsment és adatmodell kialakítását, a kormányzati nedzsmonikus aláíńs rendszer kialakítás és bevezetése, a kormányzaton belïli informati és komezése, ás rendszeré és alk inaźcok integrácioja az on-line oss rón adózás további fejleszlése és kiterjeszlése stb. jelentố sen növelné a hatekonyságot. Az onkormányzati vezetôkkel folytatott mélyinterjuim tapasztalata alapján a hivatali döntéshozatali folyamatok átláthatósága, az önkormányzati PR-kommunikáció megismerése, illetve az interaktivitás, pl. internetes szavazások, közvélemény-kutatások és az eredmények megismerése, az érdemi viták lehetôsége jelentôsen javítana az ügyfelek elégedettségén. Az önkormányzatok informatikai fejlesztésével kapcsolatban azonban nem szabad eltekinteni az ügyfelek igényeinek megismerésétól, ezért először azt kellene meghatároznia a helyhá́ćgoknak hogy mely e-szolálón feleke ténlegen igéne van. Megĺtís az ügy-

2. ábra

z egyes teljesítményorientált menedzsmenttechnikák alkalmazásának elterjedtsége az önkormányzatok körében (Forrás: Hajnal, 2007, p. 4.)

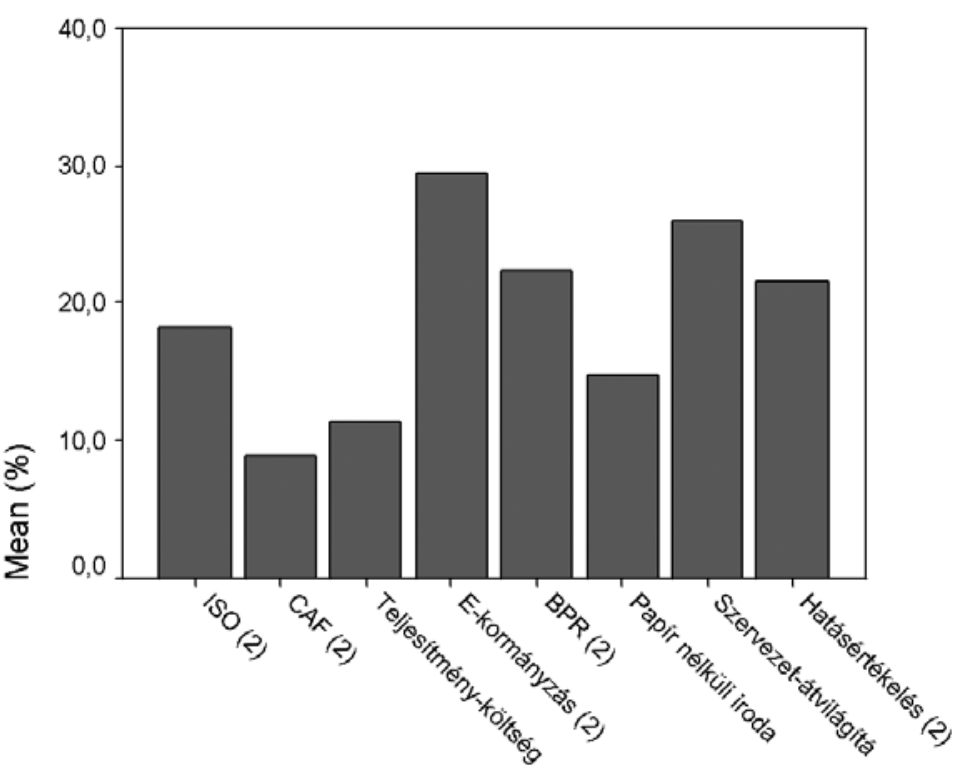

Cases weighted by SULY 
a back-office rendszerek fejlesztésére nagyobb állam támogatást kellene fordítani, mivel a munkafolyamatok racionalizálása és hatékonnyá, átláthatóvá téte alapját képezi a front-office projektek hosszú tává sikerének és az e-kormányzatba történó beruházások megtérülésének.

$\mathrm{Az}$ önkormányzatoknál szintén gyakran hasznát hatékonyságjavító eszköz a szervezetátvilágitás, valamint a hatásértékelés. A szervezetátvilágitás és a teljesítményértékelés céljából meghatározzák a fó problémákat, helyi sajátosságokat, melyek sikeres kezelése javít a munkavégzés haték núán és a szogélét javin a nón. Ezen món szolgáltatás minôségen. Ez zott eszközei a dokumentumelemzes, interjúkészítés, kérdónves adattelvétel, munkanap-fényképezés, ügymenetvizsgálat. A szervezetátvilagítást általában kevésbe támogatják a szervezet dolgozói, hiszen a többletmunka (statisztikák készítése, kérdôívek kitöltése) és pszichikai teher növekedése mellett általában szakmai és egyéb (motivációs) hiányosságokra hívhatja fel a figyelmet. Ezért fontosnak tartom a szervezetátvilágítás módszerének sikere érdekében az értékelést végzốk és a hivatali vezetés megfelelố kommunikációját, együttmúködő magatartását, továbbá az alulról jövő́ javaslatok, kezdeményezések biztatását esetleg jutalmazás például a javasolt változtatás megvalósítasub ju például a javasolt valtoztatás megvalós

A minóségbiztositás alkalmazása alapvető fontossá-

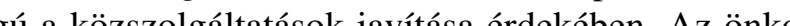

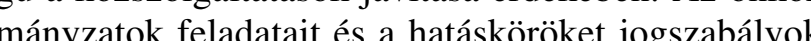

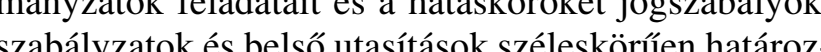

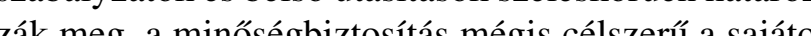
zân és bonyolult onkormányzati szolgáltatások esetében is. A minőségbiztosítás és az ISO 9001: 2000 szabvány egy olyan komplex feladatrendszer megvalosítását jelenti, amely kiterjed a szervezet irányítási struktúrájára, az alkalmazott technikai eszközök múködtetésére, adatkezelésre, adatvédelemre. Segíti az önkormányzatokat, hogy olyan minőségirányítási rendszer kialak tását és folyamatos javítását tüzzék ki célul, amely a legjobban biztosítja tevékenységük átláthatóś́gát, így többek között a gazdaságos múködtetést is. A Minóségbiztosítási Kézikönyv haszála ta, valamint eljúa

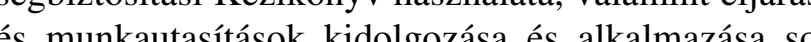
rán láthatóvá válnak a nem rendszerezett folyăsa somiatt az Önkormán a nan rendszerezt folyamatok ent az onkon vanyzat ellenérdekelt a hiányosságok feltárásában. A minőségbiztosítás gyakorlati megvalósítása komoly anyagi nehézségekbe ütközik: általáno nak nevezhetó a forráshiány, ami elsősorban a technikai feltételek biztosítása során szembetúnố, ezér legtöbbször az önkormányzatok minôségirányítási programjára már nem jut kapacitás. A minőségbizto- sítás elốnyei hosszú távon érvényesülnek. A minóség javításának egyik hatékony eszköze az ügyfélkapcsolatok tudatos építése, vizsgálata és vevőorientált javítása. A meghatározott minőség eléréséhez szükséges dologi, személyi és szervezeti feltételek biztosítása mellett nélkülözhetetlennek tartom az önkormányzat minőségfilozófiájának tudatos beépítését a szervezet kultúrájába, a külső és belsố kommunikációba és a településfejlesztés koncepciójába.

A múködés és az irányítás fejlesztésének igényére a fejlett államok élenjáró vállalatai az elmúlt évtizedben

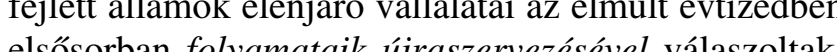
A BPR (Busizs Process Reen A BPR (Buscess Pikcess Reengineering) a folyamatok alapvetó ujragondolása es radikális átszervezése a szervezetek olyan lényeges mutatóiban, mint a költségek csökkenése, a szolgáltatás színvonala és a múködés folyamatok gyorsasága, átláthatósága. A folyamatkorszerúsités hatására javul a hatékonyság és a minôség, csökken az átfutási idó, ami jelentốsen gyorsítja a feladatok végzését, a bürokrácia mérséklésével növeli az ügyfelek elégedettségét. A feladatokat lehetôleg csak egy helyen kell elvégezni, ezért nélkülözhetetlennek tartom a duplán vagy többszörösen elvégzett munkák kiszúrése mellett a feladatkörök bővítését.

A legkevésbé alkalmazott technikák a Közös Értékelési Keretrendszer (CAF), a teljesítményorientált költségvetési formátum, valamint a papír nélküli iroda. költségvetési formátum, valamint a papír nélküli iroda ACAF sajátossága, hogy szemben a többi vállalati menedzsmentre jellemző technikával, kimondottan a közigazgatási szervezetek által történó alkalmazás céljára fejlesztették ki, az Európai Unió támogatásával. ACAF szúk körú alkalmazását elsôsorban a hazai szakmai ismeretek és tapasztalatok hiánya magyarázza.

Az egyes települési kategóriákra jellemző teljesítményorientált menedzsmenttechnikák alkalmazási gyakoriságokat a 2. táblázat mutatja.

A felmérés szerint (Hajnal, 2007) a település méretével általában csökken a modernizációs készség, a településméret növekedésével együtt viszont nő a modernizációs egyenlốtlenség. Ahogy a 2. táblázat mutatja, a nagyvárosoḱ́s a megyei jogú városok vezetése többek

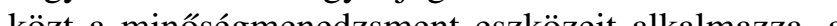
kisebb önón

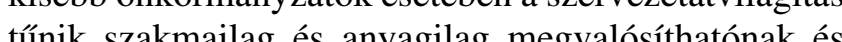
há́s

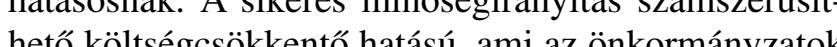

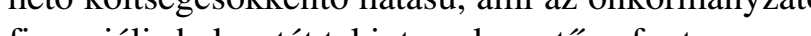
inanciális helyzetét tekintve alapvetôen fontos.

A hatékonyság javításának érdekében szükség van stratégiaalkotásra, jōvốkép- és fejlesztési koncepció megfogalmazására, illetve annak tudatosítására a lakosság és az önkormányzat munkatársai körében. Szervezeti szintú stratégia alapján lehet meghatároz(Forrás: Hajnal, 2007, p. 4.)

\begin{tabular}{|c|c|c|c|c|c|c|}
\hline & \multicolumn{5}{|c|}{ Településnagyság } & \multirow[b]{2}{*}{ Group Total } \\
\hline & kerület & m. j. v. & 10000 felett & $\begin{array}{c}2000-10000 \\
\text { között }\end{array}$ & 2000 alatt & \\
\hline & $\mathrm{col} \%$ & col $\%$ & $\operatorname{col} \%$ & $\mathrm{col} \%$ & $\operatorname{col} \%$ & col $\%$ \\
\hline ISO & $82,4 \%$ & $75,0 \%$ & $44,3 \%$ & $22,3 \%$ & $14,6 \%$ & $18,2 \%$ \\
\hline $\mathrm{CAF}$ & $47.1 \%$ & $16,7 \%$ & $23.7 \%$ & $14.9 \%$ & $5.9 \%$ & $8.8 \%$ \\
\hline Teljesítmény-köItségvetés & $41,2 \%$ & $25,0 \%$ & $17,5 \%$ & $12,8 \%$ & $10,3 \%$ & $11,4 \%$ \\
\hline E-kormányzás & $70,6 \%$ & $91,7 \%$ & $38,1 \%$ & $30,9 \%$ & $27,6 \%$ & $29,4 \%$ \\
\hline BPR & $41,2 \%$ & $33,3 \%$ & $43,3 \%$ & $34,0 \%$ & $17,8 \%$ & $22,4 \%$ \\
\hline Papír nélküli iroda & $41,2 \%$ & $50,0 \%$ & $26,8 \%$ & $17,0 \%$ & $13,0 \%$ & $14,8 \%$ \\
\hline Szervezet-átvilágítás & $58,8 \%$ & $50,0 \%$ & $49,5 \%$ & $31,9 \%$ & $22,7 \%$ & $26,1 \%$ \\
\hline Hatásértékelés & $58,8 \%$ & $33,3 \%$ & $36,1 \%$ & $26,6 \%$ & $18,9 \%$ & $21,5 \%$ \\
\hline Group Total & $100,0 \%$ & $100,0 \%$ & $100,0 \%$ & $100,0 \%$ & $100,0 \%$ & $100,0 \%$ \\
\hline
\end{tabular}

ni a célkitúzéseket, ezután elkészíthető az akcióterv, majd meghatározhatóak azok a folyamatok, amelyek egy-egy stratégiai célkitúzés megvalósításához közvetlenül járulnak hozzá. Fontos az önkormányzat külső (STEP) és belső környezetének (SWOT-analízis) elemzése, melyek segítségével jobban megismerhetó az erősségek és gyengeségek, valamint a lehetőségek és a veszélyek. Az önkormányzat vezetésével közösen, csoportmunka segítségével célszerú meghatérozni a hivatala vonatkoź kiildetést és jövóképet valározni a hivơképet, valamint kialakítani a szervezeti szintú stratégiát. A kitúzött célok teljesulése objektur mérôszámokkal mérhetô. Bakó, 2006-ban - www.kozszolgatatasmenedzsment.hu-n közzétett elemzése szerint az onkormányzatok által a kalmazott mutatók tobbnyire input-orientáltak, azaz tevékenység, a feladat ellátásához szükséges erơforrások (kiadás, munkaerô-ráfordítás) nagyságát veszik számításba, ezáltal a gazdaságosság a ráfordításra, vagyis a társadalomtól elvont eróforrások költségeire utal. Az inputmutatók könnyen meghatározhatóak, hátrányuk azonban, hogy nem eredménycentrikusak. Az önkormányzatok stratégiájának végsổ soron eredmény- és hatáscentrikusnak kell lenniük, azaz azt kell mérniük, hogy milyen mértékig sikerült elérni a kitüzött céloho knćl továb megy, az áttételes, közvete utal, a hat enc. új mán (pl. új munkahelyek száma, életminôség javulása) mutatja. Meggyôzódersen szenint a nutatószánokhoz az aktualizált stratégiából kiindulva célértékeket és felelôsōket kell kijelölni, ennek hiányában az onkormanyzati szektor munkatársaira jellemzó amúgy is alacsony motiváció és teljesítménykényszer is jelentősen csö kenhet. Célszerú a mutatószámok legalább évenkén felülvizsgálata és a tervezés aktualizálása, valamint a szükséges változtatások meghozása.

Az önkormányzati menedzsmentmódszerek alkalazásának sikeréhez szervezeti ösztönzók alkalmazására van szükség (A stratégiai menedzsment sikerének kriteriumairól bő́vebben: Kiss, 2006). Az önkormányzatok esetében azonban hiányzik a motiváló erô, ami a vállalkozásoknál hosszú távon mindennél fontosabb: a profit. E helyett olyan fogalmakkal találkozunk, mint a társadalmi szempontok hangsúlyossága, méltányosság. Visszahúzó erốt jelent továbbá önkora ́ńnzak munkatásainak a korszerúsítési változto-

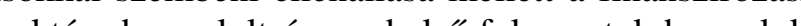
strol êr aźni szabulyozáa, a szerepkörôk tisztázallansága s az egyes munkakörook közōtti átfedés gyakorisága (Bóvebben: www.magyarorszag.hu/onkormanyzatok/ szervezetiosztonzok).

Az önkormányzati szektor sajátosságai miatt a szervezeti ösztönzók önmagukban nem jelentenek hosszú távú megoldást, ezért meggyôzoódésem szerint a hatékony és ügyfélbarát munkavégzésre történő motiváció érdekében alapvető fontosságú az önkormányzat munkatársainak egyéni teljesítménymérése, illetve ennek liggvényében történő ösztönzése a szektor teljesítméyének, eredményescégének és hatékonysâgank nölése érdekében.

\section{Konklúzió}

Az önkormányzatok feladatrendszere széles körú, melynek hatékony ellátása komoly kihívást jelent. A fejlett országoknak az üzleti szervezeteknél már jól bevalt menedzsmenteszközöket alkalmazva és a szerzett tapasztalatokra támaszkodva sikerült közigazgatásukat racionalizálniuk, hatékonyabbá és ügyfélbaráttá tenniük. 
Az Európai Unió tagállamaival összehasonlítva hazánk a kisméretú önkormányzatokkal rendelkező országok csoportjába tartozik. A magyar önkormányzati rendszer reformja során a településhálózat elaprózottságából adódó szolgáltatásszervezési és pénzügyi sajátosságokat figyelembe kell venni (Kiss, 2006). Az Európai Unió országaiban a tagállamok államháztartásának sajátossága és az önkormányzatok feladatai, vagyonosodásának alakulása rendkívül változatos képet mutat, a hatékony gazdálkodás és ügyfélbarát hivatali múködés azonban elvárásként fogalmazódik meg, aminek megvalósítása különbözó menedzsmenteszközök alkalmazását követeli. Az önkormányzati közszolgáltatások piacán az elmúlt években bekövetkezett változások új szemléletet, új stratégiát követelnek az önkormányzatoktól. Hazánkban elengedhetetlen az önkormányzatok múködésének és irányításának folyamatorientált korszerúsítése. A hagyományos kiadáscsökkentő intézkedések helyett a finanszírozási rendszer átalakítása mellett a hivatali múködés átfogó átalakítására, Új Közszolgálati Menedzsment vezetési paradigma alkalmazására és mindenekelőtt a változások igényének az önkormányzati szektorból jövő felismerésére és megfogalmazására van szükség.

Az önkormányzatok nagysága és ennek függvényében a pénzügyi helyzetük között jelentős eltérések vannak. A hátrányos helyzetú önkormányzatok számára illúziónak túnhet a minőségügyi rendszer bevezetéséról és múködtetéséról beszélni megfeleló anyagi és humán tényezók nélkül. A többcélú önkormányzati társulások megalakulása lehetôvé teszi a racionálisabb feladatellátást azokon a településeken is, amelyek erre egyébként önállóan vagy hatékonyan nem képesek. Az elvárások azonban határozottan fogalmazódnak meg mind a felettes hatóságoktól, társintézményektól, mind az állampolgárok részéról.

A minőségi közszolgáltatás iránti követelmények szervezeti eszközök használatát kényszerítik ki. A stratégiai tervezés és az ügyfélközpontú menedzsment megvalósítása nélkülözhetetlen a minőség javítása érdekében. Az önkormányzat számára fontos az érintettek elégedettségének mérése és az általuk megfogalmazott panaszok, igények, javaslatok módszeres beépítése a minőségbiztosításba. Az ösztönzô szabályozás alapelveinek egyértelmú meghatározása mellett szükség van az önkormányzatok stratégiai tervezésére és kiszámítható kistérségi jövớképének megfogalmazására. A jövốkép megvalósításához nélkülözhetetlennek tartom a reális célok kitúzését, a szükséges változtatások igényének felismerését, a változtatással szembeni ellenállás sikeres leküzdését, annak elfogadtatását a szervezet munkatársaival és a közösséggel.

\section{Felhasznált irodalom}

Beluszky P. (1999): Magyarország településföldrajza. DialógCampus Kiadó, Budapest

Bódi F. - Bóhm A. (szerk.) (2000): Sikeres helyi társadalmak. Agroinform Kiadó, Budapest

Csizmadia Z. (2003): Az önkormányzati társulások hálózati struktúrái. In: Szretykó Gy. (szerk.): A helyi társadalom szociológiai dimenziói. Comenius Kiadó, Pécs

Deli L. - Vigvári A. (2006): Decentralizáció, transzpotencia, elszámolhatóság. In: IDEA

Munkacsoport, Vitaanyag az önkormányzati reformról, kézirat Gáspár M. (1993): Helyi önkormányzati menedzsment. Lépések a teljesítményelvú és polgár közeli közigazgatás felé. Közigprint - Közigkonzult Kiadó, Csákberény

Gáspár M. (1994): Az önkormányzati váltás forgatókönyve. KÖZIGPRINT -KÖZIGKONZULT Kiadó, Budapest

Hajnal Gy. (2007): Az önkormányzati múködés korszerúsítésének irányai és lehetôségei, vezetői összefoglaló, Magyar Közigazgatási Intézet, Budapest, p. 3-11.

Hajnal Gy. - Gajdusek Gy.(2002): Hivatali határok -Társadalmi hatások. Bevezetés a hatékony közigazgatás módszertanába, Vezetői Összefoglaló, Magyar Közigazgatási Intézet, Velence, p. 11-22.

Kiss L. V. (2006): Önkormányzatok versenyképessége és finanszírozása nemzetközi összevetésben, Európai Tükör, XI. évfolyam 4. szám, p. 89-104.

Lengyel I. (2003): Verseny és területi fejlődés. JATE Press, Szeged

Norton A. (1994): International Handbook of Local and Regional Government, p. 27

Önkormányzati Törvény 1990. évi LXV. Helyi önkormányzatokról szóló törvény 1., 8 . §

Péteri G. (1994): „A vállalkozó önkormányzattól” a helyi gazdaságfejlesztésig. - Comitatus, 1. p. 14-20.

Tanács Z. (2007): Az önkormányzati feladatellátás korszerúsítése összhangban a kiemelt városfejlesztési célokkal, kézirat, Közszolgáltatási Menedzsment Portál, p. 3.

Vigvári A. (2006): Reformérett önkormányzati rendszer. Helyzetelemzés és a helyzetből kivezető út. CEO $M a$ gazin Melléklet, VII. évf. p. 2-12.

http://www.e-magyarorszag.hu/ShowBinary/repo/root/ mohu/hirkozpont/hatteranyagok

http://www.kozszolgalatimenedzsment.hu/?doc=tk_t\&t=28

http://www.kozszolgaltatasmenedzsment.hu/ downloder.php? $\mathrm{i}=692 \& \mathrm{f}=$ BakoCsaba Mutatoszamok+a+kozigazgatasban_BCS.pdf

1http://www1.worldbank.org/wbiep/decentralization/ library6/Bird-Transfer.pdf

http//:www.vg.hu/index.php?apps=cikk\&cikk=233610\&fr= hs - 83k/AllamiSzamvevoszek

Cikk beérkezett: 2008. 8. hó

Lektori vélemény alapján véglegesítve: 2008. 10. hó 